Ethiopian Journal of Environmental Studies \& Management 9(Suppl. 1): 876 - 885, 2016.

ISSN:1998-0507

Submitted: June 25, 2016

doi: http://dx.doi.org/10.4314/ejesm.v9i1.7S

Accepted: November 25, 2016

\title{
HEALTH IMPLICATIONS OF HOUSING, HUMAN WASTE DISPOSAL PRACTICES AND WATER SUPPLY IN UYO, SOUTHERN NIGERIA
}

\author{
*OLORUNSOLA, E.0. ${ }^{1}$ AND ADJE, D.U ${ }^{2}$ \\ ${ }^{1}$ Department of Pharmaceutics and Pharmaceutical Technology, University of Uyo, Uyo, \\ Nigeria \\ ${ }^{2}$ Department of Clinical Pharmacy and Pharmacy Administration, Delta State University, \\ Abraka, Nigeria
}

\begin{abstract}
This study was aimed at assessing the health implications of housing, human waste disposal practices and water supply in Uyo, Southern Nigeria. The town was demarcated into three zones $A, B$ and $C$ equivalent to the north-eastern area, southern area and northwestern area respectively. Out of the estimated one hundred and twenty two thousand three hundred and thirty eight households in the town, a total of one hundred and forty households were selected from the three zones $A, B$ and $C$ in the proportion of 40:40:60 respectively based on the number of wards per zone. Data were collected using questionnaires distributed to the head/representative of each household. Number of people per room, number of people per toilet, location of toilet, type of toilet facility and type of water supply were evaluated for each zone. Data were analyzed using Chi-square test. Zone $B$ had the largest number of people per room (2.10) while zone $C$ had the largest number of people per toilet facility (2.14). Zone $A$ had the highest proportion of households having toilet facility located within the house (95.00\%). Water closet was the most frequent toilet type in all the zones with the proportion being highest in zone $A$ ( $p$ <0.01). Borehole was observed to be the commonest source of water supply in all the zones. The status of housing facility, human waste disposal and water supply in Uyo is satisfactory. Zone A had the best facilities consistent with the high income status of the zone.
\end{abstract}

Key Words: Health implication, Housing, Toilet facility, Water supply, Uyo

\section{Introduction}

The World Health Organisation (WHO) defines environmental health as encompassing those elements of human health that are influenced by physical, chemical, biological, social and psychological factors in the environment. It also covers the theory and processes of analysing, managing and preventing those elements in the environment that have the potential of negatively affecting the health of the public either presently or in the future (WHO, 2009). The relationship between environment and health is well established and dates back to even before 1948 when the Public

*Corresponding Author: Olorunsola, E.O.

Email: olorunsolaeo@yahoo.com 
Health Act was promulgated. This Act provided for the establishment of boards to ensure proper drainage, efficient waste disposal and safe water supply (Chadwick, 1848). Poor housing, overcrowding, poor hygiene, lack of social support, improper disposal of human waste and bad water supply are factors that promote the spread of diseases (Downey and VanWilligen, 2005; Schulz, 2005; Buckley et al., 2008).

Essential components of environmental health include: availability of safe water, food safety, good housing and effective management of sewage (Madigan et al., 2002; Stams and Plugge, 2007; WHO, 2014). Improvement on physical environment normally leads to substantial gains in the health status of the people. Therefore, availability of good and accessible toilet facilities, potable water and adequate housing could be an indirect measure of disease prevention status of a community (WHO, 2014).

The effect of housing on health can be felt in two ways - direct and indirect ways (Taylor, 2001; Bailie and Wayte, 2006). The direct way is associated with the condition of housing itself. For instance, overcrowding influences the mental health and wellbeing of households due to the many social issues which arise from the inadequate space per person (Shaw, 2004). The indirect way has to do with individual and community elements such as the location of the housing, proximity to essential services and the overall functioning of the community (Bailie and Wayte, 2006). Therefore, the impact of housing on health can be mediated through its design, function, cleanliness and crowding.
Improper and inadequate human waste disposal may lead to contamination of living areas with faeces (Cameron and Hofvander, 1998). Harmful microorganisms present in human wastes are: viruses, bacteria and parasites (Lucas and Gilles, 2009). The viruses include Rotavirus; the bacteria include Shigella, Escherichia coli, Vibrio cholerae, Salmonella spp. and Campylobacter spp. while the parasites include Entamoeba histolytica, Crytosporidium, and Giardia lamblia. These organisms are implicated in many infections such as gastroenteritis, dysentery, diarrhoea, strongyloidiasis et cetera (Madigan et al., 2002).

Access to clean water is essential for healthy living. Ideally, the quantity supplied should meet domestic needs of drinking, personal hygiene, bathing and food preparation (Kabila, 2010). The water quality in terms of microbial load and chemical residues has great impact on health outcomes. Diseases associated with the consumption of water of poor quality have close association with those transmitted through human wastes (Lucas and Gilles, 2009).

Unsafe water, insufficient hygiene and poor housing account for an estimated $9.1 \%$ of the global burden of disease and $6.3 \%$ of all deaths (Kabila, 2010). Nearly half of all people in developing countries have infections or diseases associated with inadequate water supply and poor sanitation (Bartram et al., 2005). The most affected populations are children and people under condition of extreme poverty (Kabila, 2010).

No reported study on housing pattern, human wastes disposal practices or types of water supply to Uyo was obtained from literature. The major objective of this study was to determine the adequacy 
of housing, water supply and human waste disposal facilities in the study area as well as their health implications. The specific objectives were to determine the average family size per household, types of housing and toilet facilities, average number of people per room, average number of people per toilet and types of water supply in the study area.

\section{Methodology}

Setting/Design

The setting is Uyo town, capital of Akwa Ibom State located in the southsouth zone of Nigeria. Based on the 2006 population census figure of 356,964 and assuming an annual growth of $2.3 \%$, Uyo had an estimated population of 428,183 and estimated household population of 122,338 in year 2014. The town can be delineated into three zones as: high-income area, medium-income area and low-income area (Ukpong and Udofia, 2011). The study design was cross-sectional observational survey of households in Uyo, Akwa Ibom State. The study was carried out between January and June, 2014.

\section{Study Population and Sample}

The city was demarcated into three zones $\mathrm{A}, \mathrm{B}$ and $\mathrm{C}$ equivalent to NorthEastern part, Southern part and NorthWestern part respectively. These divisions are equivalent to that of Ukpong and Udofia (2011) who divided the city into high, medium and lowincome areas respectively in a previous study involving evaluation of domestic solid waste disposal practices (Figure 1).

The 2014 population of Uyo Capital City was projected from the 2006
National Population Commission (NPC) figure of 356, 964 using equation 1 based on the formula used by Ukpong and Udofia (2011).

$$
\mathrm{P}_{\mathrm{t}}=\mathrm{P}_{\mathrm{o}}(1+\mathrm{r})^{\mathrm{n}}
$$

Where:

$\mathrm{P}_{\mathrm{t}}=$ projected population

$\mathrm{P}_{\mathrm{o}}=$ population of the base year

$r=$ rate of growth $(2.3 \%)=0.023$

$\mathrm{n}=$ duration between base year and projection year (8 years).

This gave a projected population of 2014 as 428,183 .

The sample size for the study was determined using Yamane's formula as used by Ukpong and Udofia (2011).

$$
\mathrm{n}=\frac{\mathrm{N}}{1+\mathrm{N}(\mathrm{e})^{2}}
$$

Where:

$\mathrm{n}=$ sample population

$\mathrm{N}=$ finite population $(428,183)$

$\mathrm{e}=$ the level of significance $(0.05)$

This gave a sample population of 400

The pilot study carried out to determine the average family size in the study area gave a value of 3.5. Therefore, a total of 114 households must be sampled in order to get the sample population of 400 . Uyo Local Government Area has eleven (11) wards with three (3) wards in zone A, three (3) wards in zone B and five (5) wards in zone C. For the purpose of this study, 40 households were randomly selected from each of zones A and B while 60 were selected from zone $\mathrm{C}$ bringing the total to 140 households. 


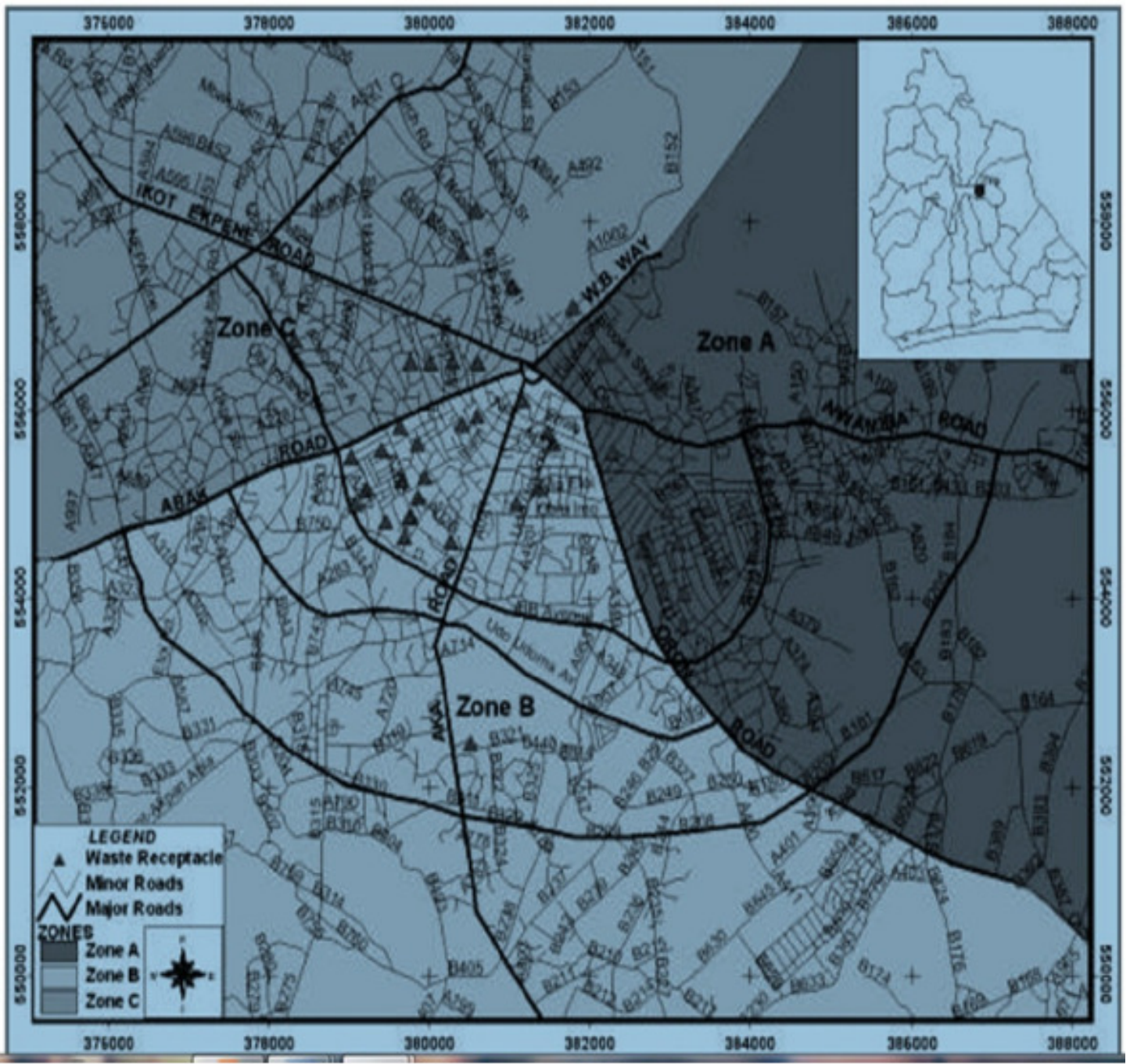

Figure 1: Map of Uyo showing the three zones A, B and C (Adapted from Ukpong and Udofia, 2011)

\section{Data Collection and Presentation}

The study was carried out using a pretested structured self-administered questionnaire that was distributed to the head or representative of each of the households. Informed consent of the respondents was obtained for the study and their privacy rights were observed. The family sizes, types of houses, source of water supply, average number of people per room, average number of people per toilet as well as nature of toilet facilities were noted for each zone.

\section{Data Analysis}

Data were presented as proportions (percentages). Chi-square test was performed to evaluate differences between categorical variables of interest in the various zones. A $p$-value of $<0.05$ was considered significant.

\section{Ethical Considerations}

Permission and approval for the study were obtained from the Ethics Committee 
of the Faculty of Pharmacy, University of Uyo, Uyo, Nigeria. The study was carried out in accordance with internationally accepted procedure and the guidelines and rules of the Faculty for experiments involving humans. Informed consent was obtained from the respondents in writing and their privacy rights were observed.

\section{Results}

The demographic characteristics of respondents are shown in Table 1. The proportion of respondents aged below 40 years ranged from $80-95 \%$ for the three zones. Zone A had the lowest proportion of families having more than 6 members $(7.5 \%)$ as well as the lowest number of 1 room apartments. There was no significant difference in the proportion of families having more than 6 members in zones $\mathrm{B}$ and $\mathrm{C}$ but their values were significantly different from that of zone A $(\mathrm{p}<0.01)$. Zone B had the largest number of people per room (Figure 2).

Table 1: Demographic characteristics of respondents $(n=140)$

\begin{tabular}{|c|c|c|c|c|c|c|c|}
\hline \multirow[t]{2}{*}{ Characteristics } & \multicolumn{2}{|c|}{ Zone A $(n=40)$} & \multicolumn{2}{|c|}{ Zone B $(n=40)$} & \multicolumn{2}{|c|}{ Zone C $(\mathrm{n}=60)$} & \multirow[b]{2}{*}{$\mathrm{p}$-value } \\
\hline & Freq. & $\%$ & Freq. & $\%$ & Freq. & $\%$ & \\
\hline \multicolumn{8}{|l|}{ Age (yr) } \\
\hline $20-29$ & 18 & 45.00 & 22 & 55.00 & 31 & 51.67 & $>0.05$ \\
\hline $30-39$ & 14 & 35.00 & 16 & 40.00 & 19 & 31.67 & $>0.05$ \\
\hline $40-49$ & 6 & 15.00 & 2 & 5.00 & 2 & 3.33 & $<0.01$ \\
\hline$\geq 50$ & 2 & 5.00 & 0 & 0.00 & 8 & 13.33 & $<0.005$ \\
\hline \multicolumn{8}{|l|}{ Family size } \\
\hline $1-2$ & 8 & 20.00 & 16 & 40.00 & 17 & 28.33 & $<0.005$ \\
\hline $3-4$ & 18 & 45.00 & 6 & 15.00 & 15 & 25.00 & $<0.001$ \\
\hline $5-6$ & 11 & 27.50 & 9 & 22.50 & 15 & 25.00 & $>0.05$ \\
\hline$>6$ & 3 & 7.50 & 9 & 22.50 & 13 & 21.67 & $<0.01$ \\
\hline \multicolumn{8}{|l|}{ Type of housing } \\
\hline 1 room & 6 & 15.00 & 12 & 30.00 & 16 & 26.67 & $<0.05$ \\
\hline 1 bed room flat & 4 & 10.00 & 8 & 20.00 & 9 & 15.00 & $>0.05$ \\
\hline 2 bed room flat & 12 & 30.00 & 10 & 25.00 & 13 & 21.67 & $>0.05$ \\
\hline 3 bed room flat & 15 & 37.50 & 5 & 12.50 & 3 & 5.00 & $<0.001$ \\
\hline 4 bed room flat & 3 & 7.50 & 5 & 12.50 & 19 & 28.67 & $<0.005$ \\
\hline
\end{tabular}




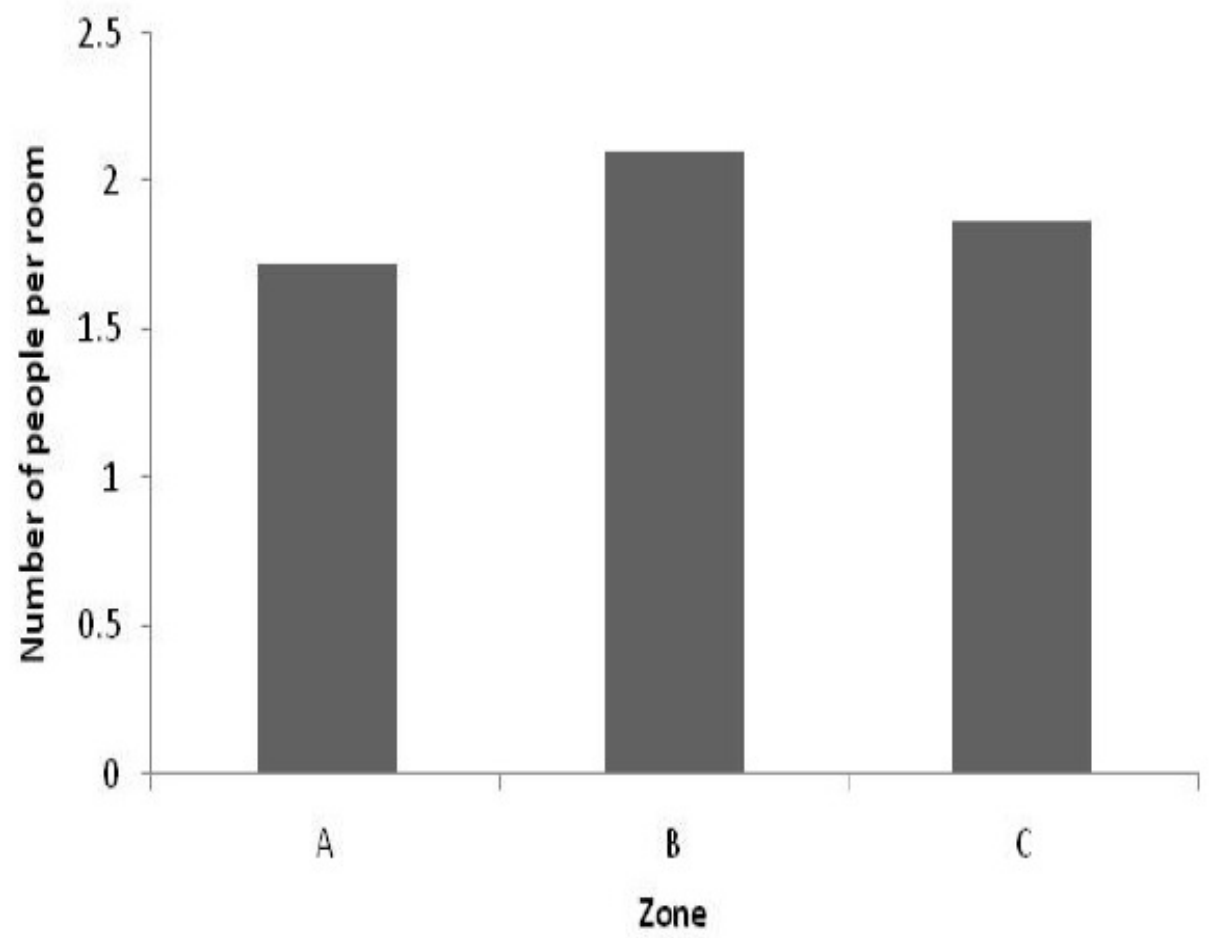

Figure 2: $\quad$ Number of people per room for each zone

Zone $\mathrm{C}$ had the largest number of people per toilet facility (Figure 3). The status of toilet facilities in the various zones is illustrated in Figure 4. The number of households having their toilet facility located within the house was higher than those having theirs located outside the house for each of the zones.
Zone A had the highest proportion of households having toilet facility located within the house. Water closet was the most prevalent toilet type in each of the zones with zone A having significantly higher proportion $(\mathrm{p}<0.01)$. Open defecation had a frequency of zero in all the zones (Table 2).

Table 2: Proportion of households using the different types of toilet facility $(n=140)$

\begin{tabular}{lccccccc}
\hline & Zone $\mathrm{A}(\mathrm{n}=40)$ & \multicolumn{2}{c}{ Zone $\mathrm{B}(\mathrm{n}=40)$} & \multicolumn{2}{c}{ Zone $\mathrm{C}(\mathrm{n}=60)$} & \\
Toilet facility & Freq. & \multicolumn{1}{c}{$\%$} & Freq. & \multicolumn{1}{c}{$\%$} & Freq. & \multicolumn{1}{l}{$\%$} & $\mathrm{p}$-value \\
\hline Open defecation & 0 & 0.00 & 0 & 0.00 & 0 & 0.00 & $>0.05$ \\
Pit (latrine) & 5 & 12.50 & 6 & 15.00 & 6 & 10.00 & $>0.05$ \\
Ventilation-improved pit & 0 & 0.00 & 1 & 2.50 & 1 & 1.66 & $>0.05$ \\
Pour flush & 7 & 17.50 & 12 & 30.00 & 17 & 28.34 & $>0.05$ \\
Water closet & 28 & 70.00 & 21 & 52.50 & 36 & 60.00 & $<0.01$ \\
\hline
\end{tabular}




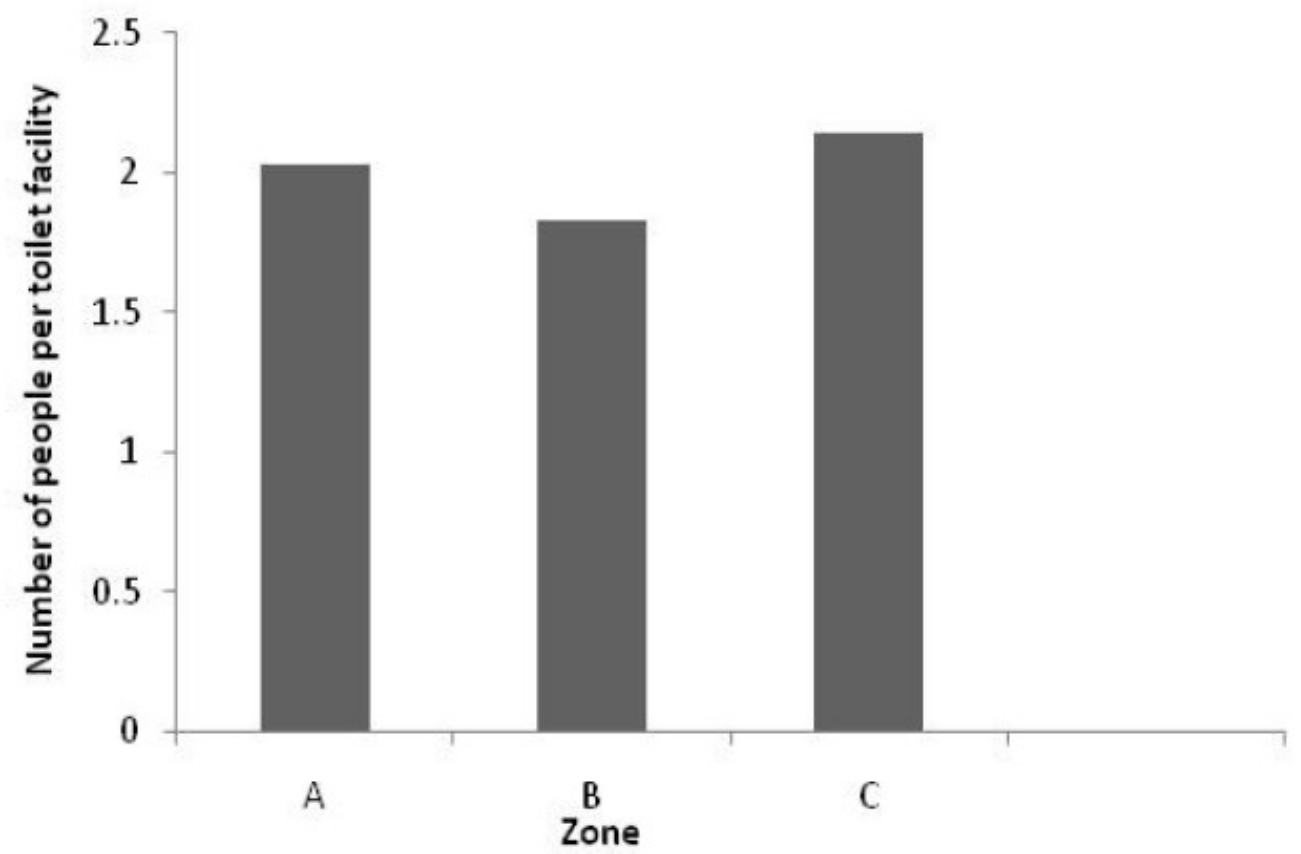

Figure 3: $\quad$ Number of people per toilet for each zone

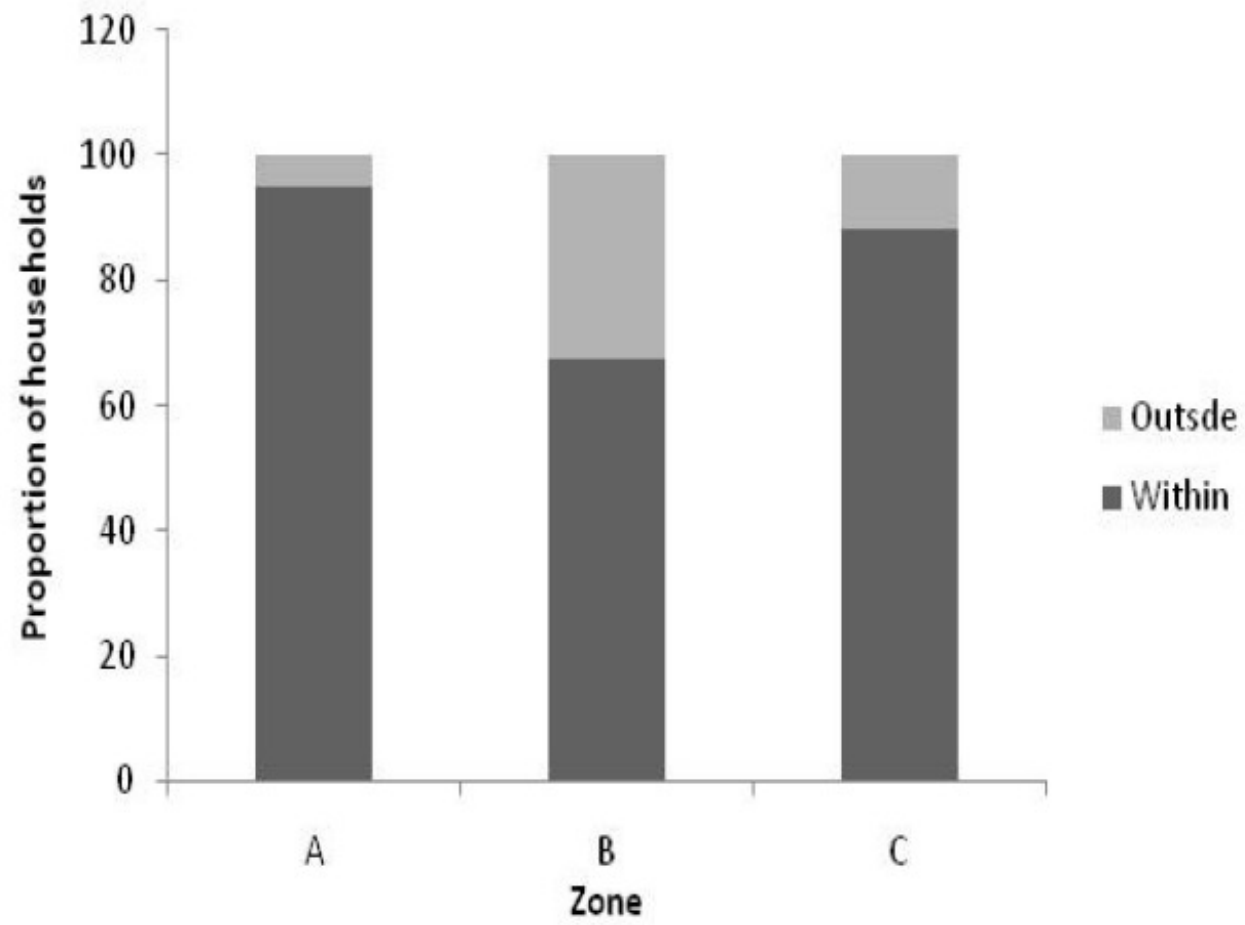

Figure 4: Proportion of households having toilet facility within and outside the house 
The sources of water supply to the different households are shown in Table 3. Borehole was observed to be the commonest source of water supply for all the zones. There was no significant difference in the proportion of households using borehole water in the different zones. The proportion of households using spring water was zero for all the zones. The proportion of households using water from stream was also zero for all the zones.

Table 3: $\quad$ Sources of water supply to the households

\begin{tabular}{lccccccc}
\hline Water & \multicolumn{2}{c}{ Zone A $(\mathrm{n}=40)$} & \multicolumn{2}{l}{ Zone B $(\mathrm{n}=40)$} & \multicolumn{2}{l}{ Zone C $(\mathrm{n}=60)$} & \\
source & Freq. & $\%$ & Freq. & $\%$ & Freq. & $\%$ & $\mathrm{p}$-value \\
\hline Tap & 12 & 30.00 & 7 & 17.50 & 10 & 16.67 & $>0.05$ \\
Borehole & 28 & 70.00 & 32 & 80.00 & 49 & 81.67 & $>0.05$ \\
Spring & 0 & 0.00 & 0 & 0.00 & 0 & 0.00 & $>0.05$ \\
Well & 0 & 0.00 & 1 & 2.50 & 1 & 1.66 & $>0.05$ \\
Stream & 0 & 0.00 & 0 & 0.00 & 0 & 0.00 & $>0.05$ \\
\hline
\end{tabular}

\section{Discussion}

Majority of the respondents were between the ages of 20 and 40 years in the three zones. This profile is consistent with that of a city undergoing rapid urbanization (Daniel and Ibok, 2013) characterized by influx of young people.

Zone A was the least congested having the smallest family size. This might indicate that this zone has the best protection against communicable diseases. This study seems to confirm the high income area designation of this zone (Ukpong and Udofia, 2011) as more than half $(>60 \%)$ had average family sizes of 3-6 and houses in this zone were predominantly 2-3 bedroom apartments. Zones $\mathrm{B}$ and $\mathrm{C}$ have higher proportion of family size greater than 6 probably as a result of large number of children and dependants. This in addition to the predorminance of 1 room apartments might justify the designation as lowincome areas (Ukpong and Udofia, 2011).

Toilet facilities located within the house is a hallmark of good housing. Majority of households in all the zones had toilet facilities located within the house (Figure 4). This would facilitate proper disposal of human waste which is important for prevention of transmission of water-borne diseases. Even though zone B has the lowest number of people per toilet facility, a substantial proportion of the toilet facilities are located outside the house signifying a need for improvement in terms of location of toilet facilities for the zone.

The high proportion of households using water closet toilet facility can be linked to the ready availability of the piped water in the three zones. Water closet system is the preferred method of disposing faeces and urine since the $S$ trap creates an effective temporary seal to the drain which prevents menace of odour and flies (Buckley et al., 2008). The pour-flush toilet is the second most common type of toilet for each of the zones. The major difference between the pour-flush and water closet is that the former requires less water for flushing and more convenient to use when water is not piped to the toilet. It is however, not as neat as the water closet. 
Zone B with the highest proportion of households having toilet facility outside the house also had the highest proportion of pour-flush toilet while the highest proportion of water closet toilets were found in zone A which has the highest proportion of toilets located within the house. Therefore, there is an association between type of toilet facility and the location of the toilet. The total absence of open defecation system in the three zones surveyed is an indication of the cosmopolitan and modern nature of the study environment. Proper disposal of human waste offers protection against faeco-orally transmitted diseases.

Majority of households in each of the zones had access to tap or borehole water. This is commendable because well water and streams are more susceptible to contamination by landfills through the surface water (Allen, 2001). The good water supply ensures adequate protection from water-borne diseases.

\section{Conclusion}

Housing standard, water supply and human waste disposal practices appear to be adequate in Uyo metropolis, Nigeria. The high income area (Zone A) offers the best protection from water- and air-borne diseases. There is a need to upgrade some facilities in the low income areas of the town to improve their health outcome.

\section{Acknowledgment}

The authors are grateful to Kamla-Raj Enterprises, Delhi, India for the permission granted on 14/06/16 for the use of Figure 1.

\section{References}

Allen, A.R. (2001). Containment landfills: The myth of sustainability. J Eng Geol, 60: 3-19.

Bailie, R.S. and Wayte, K.J. (2006). Housing and health in indigenous communities: key issues for housing and health improvement in remote Aboriginal and Torres Strait Islander communities. Australian J Rural Health, 14(5): 178-183.

Bartram, J., Lewis, K., Lenton, R. and Wright, A. (2005). Focusing on improved water and sanitation for health. Lancet, 365(9461): 810-812.

Buckley, C., Foxon, K. and Brouckaert, C. (2008). Scientific Support for the Design and Operation of Ventilated Improved Pit Latrines (VIPs) and the Efficacy of Pit Latrine Additives. Pollution Research Group, School of Chemical Engineering University of KwaZulu-Natal, KwaZulu-Natal, South Africa.

Cameron, M. and Hofvander, Y. (1998). Manual on Infant Feeding. Third Ed. Oxford University Press, London.

Chadwick, E. (1848). The 1848 Public Health Act. Available at http://www.parliament.uk/about/livi $\underline{n g}$, Accessed on 17/07/14 at 4.20 pm.

Daniel, E.E. and Ibok, E. (2013). Solid wastes disposal habits of students in Nigerian universities: A case of University of Uyo, Nigeria. IOSR $J$ Env Sci Tox Food Tech, 5(6): 4650.

Downey, L. and VanWilligen, M. (2005). Environmental stressors: The mental impacts of living near 
industrial activity. $J$ Health Soc Behaviour, 46(3): 289 - 305.

Kabila, A. (2010). Domestic water supply, sanitation and health in rural Ghana: Perspective from Nkwanta district. Ghana J Geog, 2:163-193.

Lucas, A.O. and Gilles, H.M. (2009). A New Short Textbook of Preventive Medicine for the Tropics. Bounty Press Limited, Ibadan Nigeria.

Madigan, M., Marthinko, J., Dunlap, P., Clark, D. and Brock, T. (2002). Brock Biology of Microorganisms, Tenth edition. Available at http://www.amazon.com/BrocksBiology, Accessed on 20/07/14 at $3.20 \mathrm{pm}$.

Schulz, A.J. (2005). Social and physical environment and disparities in risk factors, Available at http://www.ncbi.nlm.nih.gov. Accessed on 18/07/14 at 11.19 am.

Shaw, M. (2004). Housing and Public Health. Annual Review of Public Health, 25: 397-418.

Stams, A.J. and Plugge, C.M. (2009). Electron transfer in syntrophic communities of anaerobic bacteria and archaea. Nat Rev Microbiol, 7(8): 568-577.

Taylor, V. (2001). Health hardware for housing for rural and remote indigenous communities. In: Canyon, D. and Speare, R., eds. Rural and Remote Environmental Health 1. Brisbane: The Australasian College of Tropical Medicine: 42-49

Ukpong, I.E. and Udofia, E.P. (2011). Domestic solid waste management in a rapidly growing Nigerian city of Uyo. J. Hum. Ecol., 36(3): 229235.

WHO - World Health Organization (2009). Environmental health. Available at http://www.who.int/topics/environm ental_health/en/. Accessed on $30 / 07 / 16$ at $2.30 \mathrm{pm}$.

WHO - World Health Organization (2014). Environmental health. Available at http://www.who.int/topics/environm ental health, Accessed on $17 / 07 / 14$ at $4.19 \mathrm{pm}$. 